\title{
Distribution of Fecal Sterols, Nonylphenol, and Polycyclic Aromatic Hydrocarbons in Surface Water from Masan Bay, Korea
}

\author{
Minkyu Choi ${ }^{1}$, Yeonsu Park ${ }^{1}$, Hyo-Bang Moon ${ }^{2}$, Jun Yu ${ }^{3 *}$ and Hee-Gu Choi \\ ${ }^{1}$ Marine Environment Research Division, National Fisheries Research and \\ Development Institute (NFRDI), 408-1, Sirang-ri, Gijang-eup, \\ Gijang-gun, Busan 619-705, Korea \\ ${ }^{2}$ Department of Environmental Marine Sciences, College of Science and \\ Technology, Hanyang University, Ansan 426-791, Korea \\ ${ }^{3}$ Marine Environment Impact Assessment Center, NFRDI, 408-1, Sirang-ri, Gijang-eup, \\ Gijang-gun, Busan 619-705, Korea
}

\begin{abstract}
Fecal sterols, nonylphenolic compounds (NPs), and polycyclic aromatic hydrocarbons (PAHs) were determined in surface water from Masan Bay and its adjacent rivers in February 2005. Concentrations of coporstanol (Cop), an indicator of fecal pollution, in surface water ranged from $<10$ to $13,853 \mathrm{ng} / \mathrm{L}$, and concentrations of nonylphenol, the most toxic of the NPs, ranged from 10.2 to $481 \mathrm{ng} / \mathrm{L}$, and concentrations of PAHs ranged from 8.61 to $223 \mathrm{ng} / \mathrm{L}$. The concentrations of the compounds measured in this study were lower than or comparable to those at other locations in Korea and other countries. The contamination of Cop and PAHs in surface water was associated with the discharge from rivers passing through cities and/or industrial complexes. The NP contamination was associated with wastewater treatment plant (WWTP) effluents through outfalls as well as riverine discharge. Compared to ecotoxicological values, the concentrations of NPs from rivers, the mouths of rivers, and WWTP outfall areas exceeded guidelines, suggesting that hot spot areas may pose a potential risk to sensitive species.
\end{abstract}

Key words: Coprostanol, Nonylphenol, Riverine discharge, Wastewater treatment plant

\section{Introduction}

Masan Bay, one of the most heavily contaminated estuarine systems in Korea, was designated as part of the special management coastal area in 1983. The area is surrounded by the cities of Masan, Changwon and Jinhae cities which are highly urbanized $(>1$ million people in the drainage basin, with an average population density of 2,682 people $/ \mathrm{km}^{2}$ ) and heavily industrialized (operation of about 1,300 industrial plants). The rapid urbanization and industrialization of this area was accompanied by considerable environmental pollution and social problems. Many studies have reported on the substantial contamination in Masan Bay from toxic organic contaminants (Khim et al., 1999; Hong et al., 2003; Yim et al., 2005; Moon et al., 2008; Choi et al., 2009a, b). High concentrations of contaminants in the Masan Bay sediments were reported to be associated with

\footnotetext{
*Corresponding author: jyu@nfrdi.go.kr
}

anthropogenic activities. Thus, the pathways and fates of contaminants from anthropogenic activities must be investigated to design strategies for environmental management of risks due to toxic contaminants.

Coprostanol (Cop), a fecal sterol, has been widely used as an indicator of fecal and sewage contamination in aquatic environments because it exists in high concentrations in human feces $(40-60 \%$ of total fecal sterols excreted) (Chan et al., 1998). Distribution profiles of fecal sterols together with other related sterols can provide useful information on source identification in the marine environment (Leeming et al., 1996; Mudge and Lintern, 1999). Nonylphenolic compounds (NPs) are a group of nonionic surfactants widely used in a variety of industrial processes, and residential and commercial cleaning products since the 1940s. NPs act as endocrine disrupters and are frequently found in effluents from industrial complexes (Bennie et al., 1997; Li et al., 2004). Cop and NPs have regularly 
used to investigate the degree of contamination of surface water and sediments from wastewater (Leeming and Nichols, 1996; Elhmmali et al., 2000; Noblet et al., 2004; Diez et al., 2006; Lara-Martin et al., 2008).

Polycyclic aromatic hydrocarbons (PAHs) are ubiquitous environmental pollutants that primarily result from anthropogenic activities. PAHs are generated from incomplete fuel combustion, domestic and industrial wastewaters, and spillage of crude oil and its refined products (Hites et al., 1997; Pettersen et al., 1997). Because PAHs are toxic, carcinogenic, and mutagenic to all organisms, including humans, PAHs have been extensively studied in various environmental and biological compartments (Yim et al., 2005; Moon et al., 2007; Moon et al., 2010).

Most contaminants are transported to the coastal areas by water and eventually disappear. Investigation of surface water can provide information on present pollution and pathways of contaminants. However, little attention has focused on occurrence and distribution of organic contaminants in freshwater and saltwater from Korean coastal waters including Masan Bay. We assessed water contamination from anthropogenic impacts using the major organic contaminants (Cop, NPs, and PAHs) in urban and industrial effluents. The present study investigated fecal sterols [Cop, cholesterol (Chst), and cholestanol (Chsta)], NPs [nonylphenol (NP), nonylphenol monoethoxylate $\left(\mathrm{NP}_{1} \mathrm{EO}\right)$, and nonylphenol diethoxylate $\left.\left(\mathrm{NP}_{2} \mathrm{EO}\right)\right]$, and 16 PAHs in surface water from Masan Bay and its adjacent rivers.

\section{Materials and Methods}

\section{Sample collection}

Water samples were collected in February 2005 from six rivers (Hoewon, Sanho, Changwon, Nam, Guidong and Sini rivers) that discharge to Masan Bay and from 40 stations in Masan Bay (Fig. 1). Samples, collected by water-sampler, were separated into particulate and liquid phases. Particulate samples were isolated by filtering the water through precombusted glass fiber filters (GF/F, Whatman, Florham Park, NJ, USA). Particulate samples were stored at $-30^{\circ} \mathrm{C}$ until extraction. Liquid samples were acidified with $6 \mathrm{~N} \mathrm{HCl}$ to remove an effect of microbial degradation and stored at $4^{\circ} \mathrm{C}$.

\section{Analytical method}

Detailed descriptions of water sample extraction and cleanup procedures for fecal sterols, NPs and PAHs have been reported previously (Choi et al.,

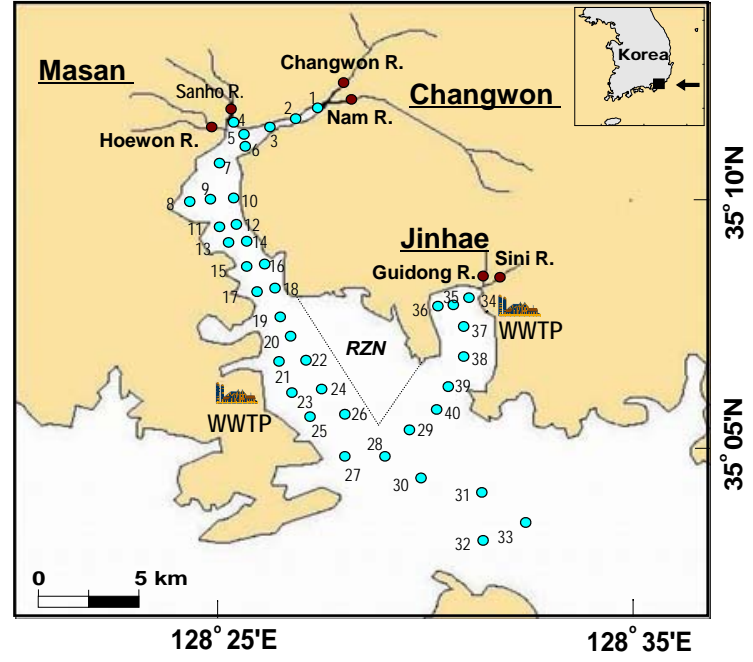

Fig. 1. Map showing the sampling locations of six rivers and seawater collected from Masan Bay, Korea. WWTP indicates the wastewater treatment plant, and RZN indicates the restricted zone for the navy.

2007; Moon et al., 2007). For fecal sterols, briefly, filter samples were placed in respective $50 \mathrm{~mL}$ Teflon centrifuge tubes with Teflon caps. A surrogate standard, 1-nonadecanol (Dr. Theodor Schuchardt \& Co, Hohenbrunn, Germany), was added to each tube, and the samples were extracted twice using dichloromethane-chloroform (ultra residue analysis; J.T. Baker, Phillipsburg, NJ). The extracts were then passed through a Florisil (60-100 mesh, reagent grade; Sigma-Aldrich, St. Louis, MO, USA) chromate-graphy column. The eluents were concentrated and derivatized using N,O-bis [trimethylsilyl] trifluo-roacetaminide (BSTFA; Sigma-Aldrich). After the addition of internal standards, the concentrated eluents were transferred to vials for instrumental analysis.

For NPs (NP, $\mathrm{NP}_{1} \mathrm{EO}$, and $\mathrm{NP}_{2} \mathrm{EO}$; Cambridge Isotope Laboratories, Andover, MA, USA), the filtered water samples were extracted twice by liquidliquid extraction, and the filter samples were extracted by a mechanical shaker using dichloromethane (ultra residue analysis; J.T. Baker). A surrogate standard, nonylphenol- ${ }^{13} \mathrm{C}_{6}$ (Cambridge Isotope Laboratories) was added to the matrix before extraction. The extracts were concentrated to about 1 $\mathrm{mL}$ under a gentle stream of dry nitrogen. The extract was concentrated to $0.5 \mathrm{~mL}$, derivatized using BSTFA, and then cleaned by passage through a Florisil chromatography column. After the addition of internal standards, the concentrated eluents were transferred to vials for instrumental analysis.

For PAHs, briefly, the filtered water samples were 
extracted twice by liquid-liquid extraction, and the filter samples were extracted for $5 \mathrm{~h}$ by reflux extraction. The extract was cleaned by passage through an activated silica gel (70-230 mesh, Merck, Whitehouse Station, NJ) column. The eluents were concentrated to approximately $1 \mathrm{~mL}$ and were evaporated at room temperature to 50 to $100 \mu \mathrm{L}$. The residues were dissolved with $50 \mu \mathrm{L}$ n-nonane (pesticide grade, Fluka, Switzerland) for instrumental analysis. This study analyzed 16 non-alkylated PAHs (48755-U, Supelco, Bellefonte, PA, USA) that are recognized as priority pollutants by the United States Environmental Protection Agency were analyzed. These include naphthalene (NaP), acenaphthylene (AcPy), acenaphthene (AcP), fluorene (Flu), phenanthrene $(\mathrm{PhA})$, anthracene $(\mathrm{AnT})$, fluoranthene (FluA), pyrene (Pyr), benzo[a]anthracene (BaA), chrysene (Chr), benzo[b]fluoranthene $(\mathrm{BbF})$, benzo $[\mathrm{k}]$ fluoranthene $(\mathrm{BkF})$, benzo[a]pyrene $(\mathrm{BaP})$, indeno [1,2,3-c,d]pyrene (InP), dibenzo[a,h]anthracene (DbA) and benzo[g,h,i]perylene (BgihP). Surrogate stan-dards (NaP-d8, AcPy-d8, FluA-d12, PhA-d10, Pyr-d10, $\mathrm{BaP}-\mathrm{d} 12$, and BghiP-d12; Cambridge Isotope Laboratories) were spiked to verify the recovery.

Fecal sterols, NPs, and PAHs were quantified using a gas chromatograph (GC-6890 series: Agilent, Wilmington, DE, USA) equipped with a mass spectrometer (5973N; Agilent). The capillary column used was a DB-5MS ( $30 \mathrm{~m}, 0.25 \mathrm{~mm}$ i.d., and $0.25 \mathrm{~m}$ film thickness, J\&W Scientific, Palo Alto, CA, USA). The MS was operated in selected ion monitoring mode, using the molecular ions of the compounds mentioned.

\section{QA/QC and statistical analysis}

All of the surrogate standards were detected with no interferences. Solvents injected before and after the injection of standards showed negligible contamination or carryover. Blanks did not contain quantifiable amounts of the target compounds. The recovery of the target compounds was based on five replicate analyses of filters and purified water (HPLC grade; J.T. Baker) spiked with the target compounds. The recoveries of fecal sterols, NPs, and PAHs were $89 \pm 5 \%, 81 \pm 12 \%$, and $75 \pm 17 \%$, respectively.

Statistics were calculated using Excel 2007 software (Microsoft, Redmond, WA, USA) for Windows, and a Pearson correlation analysis was performed to investigate the relationships between chemical compounds after data transformation using SPSS software for Windows 10.0 (SPSS 2000).

\section{Results and Discussion}

\section{Fecal sterols}

Concentrations of fecal sterols, NPs and PAHs in surface water samples are summarized in Tables 1 and 2. Concentrations of fecal sterols (Cop, Chst, and Chsta) were measured in the particulate phase because of their strong affinities to particulate matter $(\log$ Kow $=8.42)$ (Mudge and Ball, 2006). LeBlac et al. (1992) reported that the particulate faction of Cop was $94 \%$ of the total dissolved and particulate Cop in point source, river, and seawater. Fecal sterols in the present study were detected in almost all surface water samples (39 of 46 samples for Cop, 46 samples for Chst, and 38 samples for Chsta). Concentrations of Cop, an indicator of fecal pollution, in surface water ranged from $<10$ (less than the limit of detection) to $13,853 \mathrm{ng} / \mathrm{L}$ (mean: $1,324 \mathrm{ng} / \mathrm{L}$ ). Concentrations of Chst and Chsta ranged from 133 to $18,010 \mathrm{ng} / \mathrm{L}$ (mean: $2,113 \mathrm{ng} / \mathrm{L}$ ), and $<10$ to 1,992 ng/L (mean: $247 \mathrm{ng} / \mathrm{L}$ ), respectively. Chst was predominant in the fecal sterols, accounting for $75.5 \%$ $(16.0-100 \%)$ of the total sterols. It may be because Chst has various sources in the marine environment. In fact, Chst is present in many marine organisms

Table 1. Summary of fecal sterols, and nonylphenolic compounds in surface water from Masan Bay in Korea (ng/L)

\begin{tabular}{|c|c|c|c|c|c|c|c|c|}
\hline & & Coprostanol & Cholesterol & Cholestanol & Nonylphenol & $\mathrm{NP}_{1 E O^{a}}$ & NP2EO ${ }^{b}$ & $\Sigma \mathrm{NP}^{\mathrm{c}}$ \\
\hline \multirow{4}{*}{ Seawater $(n=40)$} & Min & $<10^{d}$ & 133 & $<10$ & 10.2 & 23.6 & $<$ LOD & 55.9 \\
\hline & Max & 4,099 & 7,603 & 538 & 110 & 680 & 3,631 & 4,396 \\
\hline & Mean & 310 & 749 & 66.2 & 33.2 & 130 & 415 & 578 \\
\hline & Stdev & 837 & 1,408 & 113 & 21 & 121 & 640 & 774 \\
\hline \multirow{4}{*}{ River water $(n=6)$} & Min & 4,222 & 2,536 & 1,153 & 95.5 & 587 & 784 & 1,467 \\
\hline & Max & 13,853 & 18,010 & 1,992 & 481 & 1,084 & 2,386 & 3,910 \\
\hline & Mean & 8,080 & 11,205 & 1,450 & 299 & 836 & 1,913 & 3,048 \\
\hline & Stdev & 3,942 & 5,384 & 373 & 168 & 169 & 601 & 893 \\
\hline
\end{tabular}

${ }^{a}$ nonylphenol monoethoxylate, ${ }^{b}$ nonylphenol diethoxylate, ${ }^{\mathrm{c}}$ sum of NP, NP1EO and NP2EO, ${ }^{d}$ less than limit of detection. 
Table 2. Summary of PAHs in seawater from Masan Bay in Korea (ng/L)

\begin{tabular}{|c|c|c|c|c|}
\hline & Min & Max & Mean & Stdev \\
\hline $\mathrm{NaP}$ & 0.01 & 33.6 & 6.95 & 5.85 \\
\hline AcPy & 0.06 & 0.83 & 0.34 & 0.17 \\
\hline AcP & 0.05 & 1.65 & 0.42 & 0.38 \\
\hline Flu & 0.16 & 1.77 & 0.40 & 0.27 \\
\hline $\mathrm{PhA}$ & 0.50 & 6.02 & 1.78 & 1.16 \\
\hline AnT & 0.03 & 2.75 & 0.48 & 0.49 \\
\hline FluA & 0.43 & 4.98 & 1.23 & 1.08 \\
\hline Pyr & 0.29 & 3.72 & 0.93 & 0.78 \\
\hline $\mathrm{BaA}$ & 0.09 & 4.82 & 0.80 & 1.06 \\
\hline Chr & 0.22 & 9.63 & 1.77 & 2.32 \\
\hline $\mathrm{BbF}$ & 1.30 & 29.6 & 5.13 & 5.05 \\
\hline BkF & 0.27 & 6.98 & 1.21 & 1.48 \\
\hline $\mathrm{BaP}$ & 0.12 & 15.0 & 1.79 & 2.77 \\
\hline $\ln P$ & 1.17 & 77.4 & 9.31 & 15.43 \\
\hline $\mathrm{DbA}$ & 0.44 & 54.1 & 5.94 & 10.62 \\
\hline BghiP & 0.44 & 21.2 & 2.59 & 4.07 \\
\hline$\Sigma \mathrm{CPAH}^{\mathrm{a}}$ & 5.66 & 165 & 24.2 & 33.8 \\
\hline$\Sigma \mathrm{PAH}^{\mathrm{b}}$ & 8.61 & 223 & 41.1 & 46.8 \\
\hline
\end{tabular}

${ }^{a}$ Sum of the six carcinogenic PAHs of IARC recommendation.

${ }^{\mathrm{b}} \mathrm{Sum}$ of total sixteen PAHs.

from plankton to fish as well as domestic sewage discharge (Mudge and Seguel, 1999; Peng et al., 2002).

Cop concentrations in the present study were lower than or comparable to those reported for other locations; Mokpo coast (94 to 7,568 ng/L) (Choi et al., 2007 ) and Masan Bay, Korea ( $<$ LOD to $23,088 \mathrm{ng} / \mathrm{L}$ ) (Choi et al., 2005), Mekong delta, Vietnam $(<\mathrm{ND}$ to $97,100 \mathrm{ng} / \mathrm{L}$ ) (Isobe et al., 2004), and the Po River, Italy (8,300 to $9,200 \mathrm{ng} / \mathrm{L})$ (Gilli et al., 2006).

Cop concentrations decreased with increasing distance from land (Fig. 2). This distribution is consistent with a representative trend of toxic organic contaminants observed in Masan Bay (Khim et al., 1999; Yim et al., 2005; Choi et al., 2009b). The distribution may have been impacted by land-based sources and an outside-bound net transport/advection. Cop concentrations greater than $1,000 \mathrm{ng} / \mathrm{L}$ were found in all rivers and the mouths of rivers (stations M1, M2, and M4). The concentrations of Cop in the six rivers (mean \pm standard deviation; 8,080 $\pm 3,942$ $\mathrm{ng} / \mathrm{L})$ were about 25 times higher than those $(310 \pm$ $837 \mathrm{ng} / \mathrm{L}$ ) observed in the seawater from Masan Bay. Profiles of fecal sterols such as Cop/(Cop+Chsta) and Cop/Chst, were provided. Cop/(Cop+Chsta) and Cop/Chst ratios, which are useful indicators of urban sewage input showed higher values in sewage (Leeming et al., 1996; Mudge and Lintern, 1999; Mudge and Seguel, 1999). Cop/(Cop+Chsta) ratios ranged from 0.16 to 0.88 , and Cop/Chst ratios were -
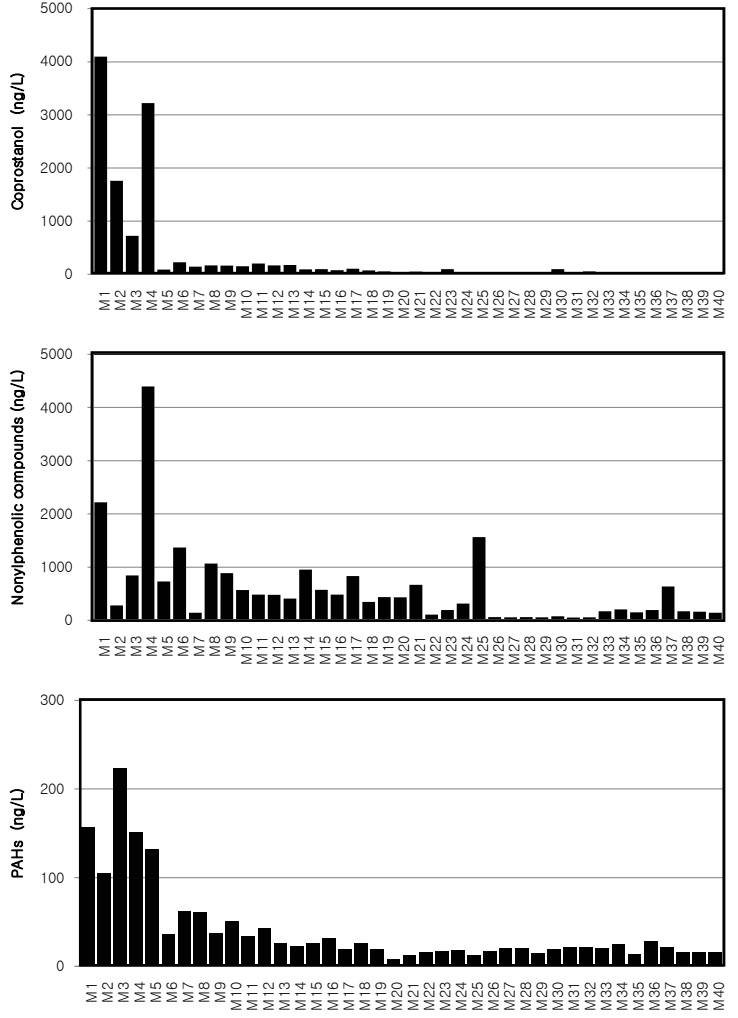

Fig. 2. Spatial distribution of coprostanol, $\Sigma N P$ (the sum of NP, $\mathrm{NP}_{1} \mathrm{EO}$ and $\mathrm{NP}_{2} \mathrm{EO}$ ), and $\Sigma \mathrm{PAH}$ (sum of 16 PAHs) in seawater from Masan Bay, Korea.

4.54. High values were found in rivers and the mouths of rivers. Spatial distribution of the ratios in seawater was similar to that of Cop concentrations $(r=0.878-0.881)$. These results indicate that riverine discharge is an important source of fecal pollution in Masan Bay.

Riverine mass discharge of Cop into Masan Bay can be estimated by using the flow rates reported by Choi et al. (2005). The results showed that the input of Cop from the six rivers was $880 \mathrm{mg} /$ day, and the input from Sanho, Changwon, and Nam rivers contributed to $88 \%$ of the total riverine discharge, suggesting that the three rivers are main routes of domestic effluents to Masan Bay.

\section{Nonylphenolic compounds}

Measurable levels of NPs were detected in 46 of 46 samples for $\mathrm{NP}, 46$ samples for $\mathrm{NP}_{1} \mathrm{EO}$, and 41 samples for $\mathrm{NP}_{2} \mathrm{EO}$. Concentrations of $\mathrm{NP}$, which is the most toxic of the NPs and has the greatest potential for bioaccumulation, ranged from 10.2 to $481 \mathrm{ng} / \mathrm{L}$ (mean: $67.9 \mathrm{ng} / \mathrm{L}$ ). $\mathrm{NP}_{1} \mathrm{EO}$ and $\mathrm{NP}_{2} \mathrm{EO}$ were found at concentrations ranging from 23.6 to 1,084 ng/L (mean: $222 \mathrm{ng} / \mathrm{L}$ ) and from $<20$ to $3,631 \mathrm{ng} / \mathrm{L}$ 
(mean: $608 \mathrm{ng} / \mathrm{L}$ ), respectively. The composition of NPs in surface water was $\mathrm{NP}_{2} \mathrm{EO}>\mathrm{NP}_{1} \mathrm{EO}>\mathrm{NP}$. The composition patterns of NPEOs can be divided into three categories; (i) $\mathrm{NP}_{2} \mathrm{EO}>\mathrm{NP}_{1} \mathrm{EO}>\mathrm{NP}$, (ii) $\mathrm{NP} 2 \mathrm{EO} \approx \mathrm{NP}_{1} \mathrm{EO}<\mathrm{NP}$, and (iii) $\mathrm{NP}_{2} \mathrm{EO}>\mathrm{NP}>\mathrm{NP}_{1} \mathrm{EO}$ (Hong et al., 2010). The composition of case (i) indicates that the sources of NPs are closer than the sources of pollution in case (ii). For case (iii), the composition pattern can be explained by differences in degradation and supply rates between long chain NPEOs that degrade to $\mathrm{NP}_{2} \mathrm{EO}$, and $\mathrm{NP}_{2} \mathrm{EO}$ that degrades to $\mathrm{NP}_{1} \mathrm{EO}$ and/or NP. The composition patterns in the present study reflect the introduction of fewer degradation products of NPEOs (nonylphenol polyethoxylates).

Compared to NP concentrations reported in Korea, the concentrations of NP in the present study were much lower than that in the Shihwa Lake and its surrounding creeks (up to 26,000 ng/L) (Li et al., 2004), and comparable to those in Mokpo coast, Korea (10-770 ng/L) (Choi et al. 2007). This result was within the ranges reported for different countries; Japan (50-1100 ng/L) (Hayakawa et al., 2001; Isobe et al., 2001), China (100-7,300 ng/L) (Shao et al., 2005), Taiwan (1800-10,000 ng/L) (Ding et al., 1999), the United States (<LOD to $640 \mathrm{ng} / \mathrm{L}$ ) (Naylor et al., 1992), Canada (<LOD to $920 \mathrm{ng} / \mathrm{L}$ ) (Bennie et al., 1997), Germany (10-400 ng/L) (Zellenr and Kalbfus, 1997), and Switzerland (<LOD to $480 \mathrm{ng} / \mathrm{L}$ ) (Ahel et al., 2000).

Concentrations of $\Sigma \mathrm{NP}$ (the sum of $\mathrm{NP}, \mathrm{NP}_{1} \mathrm{EO}$, and $\mathrm{NP}_{2} \mathrm{EO}$ ) decreased with increasing distance from land (Fig. 2). Concentrations of $\Sigma \mathrm{NP}$ greater than 1,000 $\mathrm{ng} / \mathrm{L}$ were found at six rivers, the mouths of the rivers (M1 and M4), and the wastewater treatment plant (WWTP) outfall area (M25). The mean concentration of $\Sigma \mathrm{NP}$ in the rivers $(3,048 \pm 893 \mathrm{ng} / \mathrm{L})$ was about five times higher than that $(578 \pm 74 \mathrm{ng} / \mathrm{L})$ in the seawater from Masan Bay, indicating that an important source for NPs is riverine discharge.

Relatively high concentrations in the WWTP effluent outfall areas (M25 and M37) imply that WWTP effluents containing NPs are discharged into the bay. Although NPs are highly treatable in WWTPs with biological treatment facilities, effluent from WWTPs is still considered one of the major sources of NP and short-chain NPEOs due to incomplete removal and degradation of these surfactants (Ferguson et al., 2001; Isobe et al., 2001). Moon et al. (2008) reported heavy contamination of WWTP outfall areas by chemicals associated with industrialized effluents (PCDDs/Fs, doxins-like PCBs, NPs, and PBDEs). The major sources of industrial wastewater contamination in Masan Bay may be riverine discharge and WWTP effluents.

In the riverine mass discharge of $\Sigma \mathrm{NP}$, the input of $\Sigma \mathrm{NP}$ from the six rivers was $420 \mathrm{mg} / \mathrm{day}$, and the input from Sanho, Changwon, and Nam rivers contributed to $81 \%$ of the total riverine discharge. The mass discharge pattern of $\Sigma \mathrm{NP}$ was similar to that of Cop, indicating that the three rivers are the main routes of industrial and domestic effluents.

\section{Polycyclic aromatic hydrocarbons}

All of the PAHs compounds were detected in all the seawater samples ( 40 of 40 samples). $\Sigma \mathrm{PAH}$ (the sum of $16 \mathrm{PAH}$ compounds) in seawater ranged from 8.61 to $223 \mathrm{ng} / \mathrm{L}$ (mean: $40.6 \mathrm{ng} / \mathrm{L}$ ). The sum of the six potential carcinogenic PAHs (the sum of $\mathrm{BaA}, \mathrm{BbF}$, $\mathrm{BkF}, \mathrm{BaF}, \mathrm{InP}$, and $\mathrm{DbA}$ ) (IARC, 1984), ranged from 5.66 to $165 \mathrm{ng} / \mathrm{L}$ (mean $23.8 \mathrm{ng} / \mathrm{L}$ ), accounting for $52 \%$ of $\Sigma \mathrm{PAH}$ in seawater. The predominant compounds were $\mathrm{NaP}, \mathrm{BbF}, \mathrm{InP}, \mathrm{DbA}$, and BghiP, collectively accounting for $75 \pm 7.6 \%$ of $\Sigma \mathrm{PAH}$.

Concentrations of $\Sigma \mathrm{PAH}$ in the present study were comparable to those in Mokpo coasts (mean $28 \mathrm{ng} / \mathrm{L}$ ) (Moon et al., 2007). However, the $\Sigma \mathrm{PAH}$ concentrations in the study were lower than those reported in the following coastal regions: Deep Bay, South China (mean: $69 \mathrm{ng} / \mathrm{L}$ ) (Qiu et al., 2009), Yangtze estuary (mean: $183 \mathrm{ng} / \mathrm{L}$ ) (Sicre et al., 1993), Seine River (mean: $204 \mathrm{ng} / \mathrm{L}$ ) (Fernandes et al., 1997), and Bahia Blanca estuary, Argentina (mean: $700 \mathrm{ng} / \mathrm{L}$ ) (Arias et al., 2009).

Spatial distribution of $\Sigma \mathrm{PAH}$ in seawater showed a clear decreasing trend from inner to outer locations (Fig. 2). Concentrations of $\Sigma \mathrm{PAH}$ greater than $100 \mathrm{ng} / \mathrm{L}$ were found in the mouths of rivers (stations M1, M2, M3, M4, and M5), and con-centrations greater than $50 \mathrm{ng} / \mathrm{L}$ were in harbor areas (stations M7, M8, and M10). Thus, the major source of PAHs in seawater is riverine discharge and shipping traffic is a minor source.

\section{Correlations between contaminants}

The results of correlation analysis for Cop, $\Sigma \mathrm{NP}$, and $\Sigma \mathrm{PAH}$ concentrations in seawater are shown in Fig. 3. The correlations between contaminants showed positive coefficients $(r=0.498-0.704, p<$ 0.005), indicating that they may have similar discharge points, transport, mixing and deposition in the Masan Bay. A highly significant correlation was found between the concentrations of Cop and $\Sigma \mathrm{PAH}$ $(r=0.704)$, indicating that these contaminants primarily originated from riverine discharge. The relationships of $\Sigma \mathrm{NP}$ with Cop and $\Sigma \mathrm{PAH}$ were 

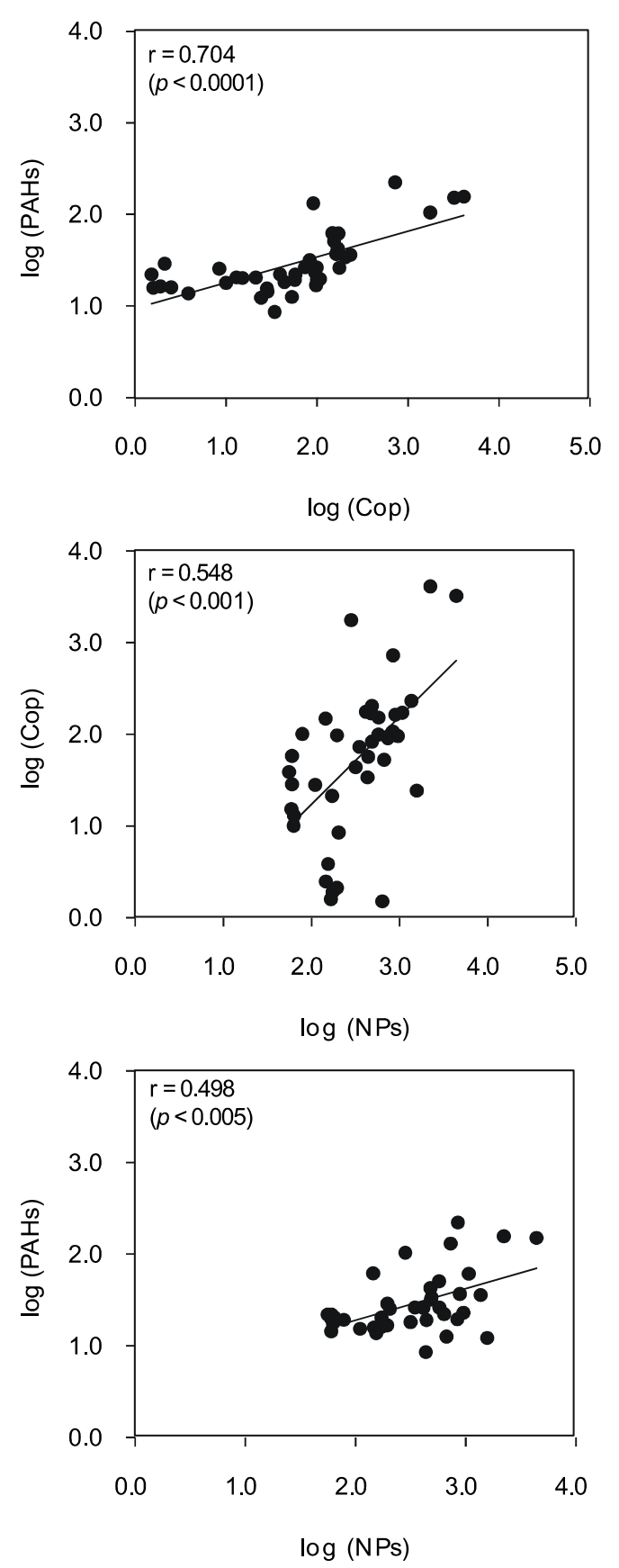

Fig. 3. Correlation between coprostanol, $\Sigma N \mathrm{~N}$, and $\Sigma$ PAH concentrations in seawater from Masan Bay, Korea.

relatively low $(r=0.548$ and 0.498$)$. It may be because the NP contamination was associated with WWTP effluents through outfalls as well as river discharge.

\section{Ecological concerns}

Trace levels of NPs and PAHs can cause chronic effects and disrupt the endocrine systems of aquatic organisms. Concentrations of NPs and PAHs analyzed in the present study were compared to screening and ecotoxicological values, to evaluate the ecotoxicological risk on aquatic organisms.

Concentrations of PAHs (AcP, Flu, PhA, AnT, FluA, Pyr, BaA, BaP, InP, and DbA) in the present study were two or three orders of magnitude lower than marine screening benchmarks of PAHs for ecological risk assessment (US EPA, 2009), suggesting that contamination of PAHs along Masan Bay is categorized in the low range.

Guidelines and ecotoxicological values for NPs in water have been proposed in various countries to protect aquatic life. The US and European regulatory standards for NP are $1,000 \mathrm{ng} / \mathrm{L}$. The Ministry of the Environment of Japan also suggested that the predicted no effect concentration of NP is $608 \mathrm{ng} / \mathrm{L}$ (Furarchi et al., 2004). The Netherlands proposed maximum permissible concentrations (MPCs) for NP $(330 \mathrm{ng} / \mathrm{L})$ and NP1EO plus NP2EO (120 ng/L) in water (Jonkers et al., 2005). Environment Canada (2002) proposed the water quality guidelines for $\Sigma N P$ $(1,000 \mathrm{ng}$ toxic equivalency (TEQ)/L for freshwater and $700 \mathrm{ng} \mathrm{TEQ} / \mathrm{L}$ for seawater) using toxic equivalency factors like dioxins and furans, to consider the additive effects of NP and NPEOs.

NP concentrations measured in the present study did not exceed water quality guidelines, and showed that $7 \%$ of 46 water samples exceeded the MPC (330 g/L) (Fig. 4). However, for NPEOs, the NP1EO plus NP2EO concentrations were greater than MPC (120

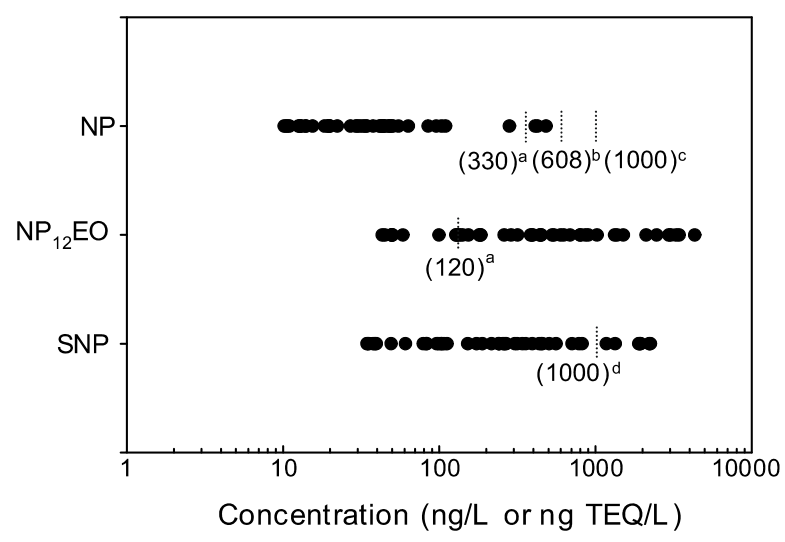

Fig. 4. Concentrations of nonylphenolic compounds with comparison of screening values reported elsewhere. ${ }^{a}$ maximum permissible concentrations for $(\mathrm{NP1EO}+\mathrm{NP2EO})$ and NP in the Netherlands (Jonkers et al., 2005), 'bredicted no effect concentration of NP in Japan (Furachi et al., 2004), ${ }^{c}$ regulatory standard for NP in USA and Europe, and dwater quality guideline of NPs in Canada (Environment Canada, 2002). 
$\mathrm{ng} / \mathrm{L}$ ) for $83 \%$ of 46 samples, and the $\Sigma \mathrm{NP}$ concentrations were greater than the Canadian guidelines for $83 \%$ of the six river samples and $10 \%$ of 40 seawater samples. These results indicate that hot spot areas such as rivers, the mouths of rivers, and WWTP outfall areas may pose a potential risk to aquatic organisms. Therefore, continuous monitoring of NPs in Korean coastal waters including urbanized, industryalized and sewage affected estuaries may be necessary.

\section{Acknowledgments}

This work was funded by a grant from the National Fisheries Research \& Development Institute (NFRDI, RP-2010-ME- 017), Korea.

\section{References}

Ahel M, Molnar E, Ibric S and Giger W. 2000. Estrogenic metabolites of alkylphenol ethoxylates in secondary sewage effluents and rivers. Water Sci Technol 42, 1522.

Arias AH, Spetter CV, Freije RH and Marcovecchio JE. 2009. Polycyclic aromatic hydrocarbons in water, mussels (Brachidontes sp. Tagelus sp.) and fish (Odontesthes sp.) from Bahia Blanca Estuary, Argentina. Estuar Coast Shelf Sci 85, 67-81.

Bennie DT, Sullivan CA, Lee HB, Peart TE and Maguire RJ. 1997. Occurrence of alkylphenols and alkylphenol mono- and diethoxylates in natural waters of the Laurentian Great Lakes basin and the upper St. Lawrence River. Sci Total Environ 193, 263-275.

Chan K, Lam MHW, Poon K, Yeung H and Chiu TKT. 1998. Application of sedimentary fecal stanols and sterols in tracing sewage pollution in coastal waters, Wat Res 32, 225-235.

Choi M, Moon HB, Kim SS and Lee Y. 2005. Distribution of sewage-derived organic matter using fecal sterol in Masan Bay, Korea. J Environ Sci 14, 481-490 (in Korean).

Choi M, Choi HG, Moon HB, Yu J, Kang SK and Choi SK. 2007. Sources and distributions of organic wastewater compounds on the Mokpo Coast of Korea. J Fish Sci Technol 10, 205-214.

Choi M, Choi HG, Moon HB, Kim GY. 2009a. Sources and distributions of organic wastewater compounds on the Mokpo Coast of Korea. J Fish Sci Technol 10, 205214.

Choi M, Moon HB, Yu J, Kim SS, Pait AS and Choi HG. 2009 b. Nationwide monitoring of nonylphenolic compounds and coprostanol in sediments from Korean coastal waters. Mar Polutl Bull 58, 1086-1092.
Ding WH, Tzing SH and Lo JH. 1999. Occurrence and concentrations of aromatic surfactants and their degradation products in River waters of Taiwan. Chemosphere 38, 2597-2606.

Diez S, Jover E, Albaiges J and Bayona JM. 2006. Occurrence and degradation of butyltins and wastewater marker compounds in sediments from Bar-celona harbor, Spain. Environ Int 32, 858-865.

Elhmmali MM, Roberts DJ and Evershed RP. 2000. Combined analysis of bile acids and sterols/stanols from riverine particluates to assess sewage discharges and other fecal sources. Environ Sci Technol 34, 39-46.

Environment Canada. 2002. Canadian environmental quality guidelines for nonylphenol and its etho-xylateds (Water, sediment, and soil) the protection of aquatic life: nonylphenol and its ethoxylates. National guidelines and standards office, Environmental quality branch, Environment Canada, report 1-3, Ottawa, Canada.

Ferguson PL, Iden CR and Brownawell BJ. 2001. Distribution and fate of neutral alkylphenol ethoxylate metabolites in a sewage-impacted urban estuary. Environ Sci Technol 35, 2428-2435.

Fernandes MB, Sicre MA, Boireau A and Tronczynski J. 1997. Polyaromatic hydrocarbon (PAHs) distributions in the Seine River and its estuary. Mar Pollut Bull 34, 857-867.

Furaichi T, Kannan K, Giesy JP and Masunaga S. 2004. Contribution of known endocrine disrupting substances to the estrogenic activity in Tama River water samples from Japan using instrumental analysis and in vitro reporter gene assay. Wat Res 38, 4491-4501.

Gilli G, Rovere R, Traversi D, Schiliro T and Pignata C. 2006. Faecal sterols determination in wastewater and surface water. J Chromatogr 843, 120-124.

Hayakawa S, Sarai E and Yamakawa M. 2001. Survey of endocrine disrupter in river water in Mie Prefecture. An Annual Report of the Mie Research Institute of Health and Environment 46, 1-6.

Hites RA, Laflamme RE and Farrington JW. 1997. Polycyclic aromatic hydrocarbons in recent sediments: the historical record. Science 198, 829-831.

Hong S, Won EJ, Ju HJ, Kim MS and Shin KH. 2010. Current nonylphenol pollution and the past 30 years record in an artificial Lake Shihwa, Korea. Mar Pollut Bull 60, 303-313.

Hong SH, Yim UH, Shim WJ, Oh JR and Lee IS. 2003. Horizontal and vertical distribution of PCBs and chlorinated pesticides in sediments from Masan Bay, Korea. Mar Pollut Bul1 46, 244-253.

IARC (International Agency for Research on Cancer). 1984. "overall evaluation of carcinogenicity: An updating of IAPC monographs”, Vol. 1-42. pp 1-477. 
Lyon, France.

Isobe T, Nishiyama H, Nakashima A and Takada H. 2001. Distribution and behavior of nonylphenol, oc-tylphenol and nonylphenol monoethoxylate in Tokyo metropolitan area: Their association with aquatic particles and sedimentary distribution. Environ Sci Technol 35, 1041-1049.

Isobe KO, Taroa M, Chiem NH, Minh LY and Takada $\mathrm{H}$. 2004. Effect of environmental factors on the relationship between concentrations of coporstanol and fecal indicator bacteria in tropical (Mekong Delta) and temperate (Tokyo) Freshwaters. Appl Environ Microbiol 70, 814-821.

Jonkers N, Laane RWPM and De Voogt P. 2005. Sources and fate of nonylphenol ethoxylates and their metabolites in the Dutch coastal zone of the North Sea. Mar Chem 96, 115-135.

Khim JS, Kannan K, Villenuve DL, Koh CH and Giesy JP. 1999. Characterization and distribution of trace organic contaminants in sediment from Masan Bay, Korea. 1. Instrumental analysis. Environ Sci Technol 33, 41994205.

Lara-Martin PA, Gomez-Parra A and Gonzalez-Mazo E. 2008. Sources, transport and reactivity of anionic and non-ionic surfactants in several aquatic ecosystems in SW Spain: A comparative study. Environ Pollut 156, 36-45.

LeBlac LA, Latimer JS, Ellis T and Quinn JG. 1992. The Geochemistry of coprostanol in waters and surface sediments from Narragansett Bay Estuar Coast Shelf Sci. 34, 439-458.

Leeming R, Ball A, Ashbolt N and Nichols P. 1996. Using faecal sterols from humans and animals to distinguish faecal pollution in receiving waters. Wat Res 30, 28932900.

Leeming R and Nichols PD. 1996. Concentrations of coprostanol that correspond to existing bacterial indicator guideline limits. Wat Res 30, 2997-3006.

Li D, Kim M, Oh JR and Park J. 2004. Distribution characteristics of nonylphenols in the artificial Lake Shihwa, and surrounding creeks in Korea. Chemosphere 56, 783-790.

Moon HB, Kang SK, Kim HS, Choi M, Yu J, Choi HG and Park JS. 2007. Polycyclic aromatic hydrocarbons (PAHs) in seawater and marine sediments from Mokpo Coast in Korea. J Kor Soc Environ Anal 10, 83-90.

Moon HB, Yoon SP, Jung RH and Choi M. 2008. Wastewater treatment plants (WWTPs) as a source of sediment contamination by toxic organic pollutants and fecal sterols in a semi-enclosed bay in Korea. Chemosphere 73, 880-889.

Mudge SM and Ball AS. 2006. Sewage In: Environmental Forensics: A contaminant Specific Approach Eds. Morrison, R. And Murphy, B. Elsevier, pp 533.

Mudge SM and Lintern DG. 1999. Comparison of sterol biomarkers for sewage with other measures in Victoria Harbour, B.C., Canada. Estuar Coast Shelf Sci 48, 27-38.

Mudge SM and Seguel CG. 1999. Organic contamination of San Vicente Bay, Chile Mar Pollut Bul1 38, 10011021.

Naylor CG, Mieure JP, Adams WJ, Weeks JA, Castaldi FJ, Ogle LD and Romano RR. 1992. Alkylphenol ethoxylates in the environment. J Am Oil Chem Soc 69, 695-703.

Noblet JA, Young DL, Zeng EY and Ensari S. 2004. Use of fecal steroids to infer the sources of fecal indicator bacteria in the Lower Santa Ana River Watershed, California: Sewage is unlikely a significant source. Environ Sci Technol 38, 6002-6008.

Peng XZ, Zhang G, Mai BX, Min YS and Wang ZS. 2002. Spatial and temporal trend of sewage pollution indicated by coprostanol in Macao Estuary, southern China. Mar Pollut Bull 45, 295-299.

Pettersen H, Anf C and Broman D. 1997. Impact of PAH outlets from an oil refinery on the receiving water areasediment trap fluxes and multivariate statistical analysis. Mar Pollut Bull 34, 85-95.

Qiu YW, Zhang G, Liu GQ, Guo LL, Li XD and Wai O. 2009. Polycyclic aromatic hydrocarbons (PAHs) in the water column and sediment core of Deep Bay, South China. Estuar Coast Shelf Sci 83, 60-66.

Sicre MA, Broyelle I, Lorre A and Saliot A. 1993. Sources and transport of particulate hydrocarbons in the mesotidal Changjiang Estuary. Estuar Coast Shelf Sci 37, 557-573.

Shao B, Hu J, Yang M, An W and Tao S. 2005. Nonylphenol and nonylphenol ethoxylates in River water, drinking water, and fish tissues in the Area of Chongqing, China. Arch Environ Contam Toxicol 48, 467-473.

US EPA. 2009. Marine Screening Benchmarks. US Environmental Protection Agency. Available at http://www.epa.gov/reg3hwmd/risk/eco/btag/sbv/ marine /screenbench.htm (Accessed 8.4.2010).

Yim UH, Hong SH, Shim WJ and Chang M. 2005. Spatiotemporal distribution and characteristics of PAHs in sediments from Masan Bay, Korea. Mar Pollut Bull 50, 319-326.

Zellenr A and Kalbfus W. 1997. In: Oldernbourg, R. (Ed.), Munchener Beitrage zur Abwasser-, Fischerer- und Fluss-biologie, Bayerisches Landesamt fur Wasserwirischaft, Munchen, Germany, 50-55p.

(Received 5 July 2010; Revised 1 September 2010; Accepted 10 September 2010) 